\title{
Islam Inklusif: \\ Konstruksi Pemikiran untuk Dialog Umat beragama di Indonesia
}

\author{
Tasman \\ Fidkom UIN Syarif Hidayatullah Jakarta \\ tasman@uinjkt.ac.id
}

\begin{abstract}
Abstrak,
Artikel ini ingin menjelaskan bahwa Indonesia adalah salah satu negara yang paling pluralistik masyarakatnya. Mayoritas penduduknya memeluk agama Islam, tetapi secara religio-politik dan ideologis, Indonesia bukan negara agama, tetapi juga bukan negara sekular". Di negeri ini, agama agama diberi ruang untuk bergerak bebas, tumbuh dan berkembang sepanjang tidak melanggar institusi dan batas-batas toleransi antar umat beragama. Komunitas religius yang beraneka ragam tersebut masing-masing, mempunyai orientasi kehidupan sendiri. Negeri ini mengakui pluralitas masyarakat, yang diharapkan oleh konstitusi negeri ini, yaitu dengan keanekaragaman itu pemeluk agama-agama dapat berlomba-lomba dalam berbuat dan mengisi pembangunan.

Pancasila sebagai ideologi merupakan titik pertemuan berbagai kelompok kepentingan, karenanya Pancasila adalah hasil kesepakatan nasional dan konsensus masyarakat Indonesia. Pancasila menjadi landasan filosofis toleransi umat beragama di Indonesia, walaupun secara eksplisit bahwa Pancasila sangat dipenuhi oleh nilainilai keislaman, ia juga terkadang diiterpretasikan sebagai sekularisme versi Indonesia. Kemajemukan atau pluralitas umat manusia merupakan kenyataan yang tak terbantahkan. Maka pluralitas meningkat menjadi pluralisme, yaitu sistem nilai yang memandang secara positif terhadap kemajemukan itu sendiri, dengan menerimanya sebagai kenyataan dan berbuat sebaik mungkin berdasarkan kenyataan itu. Dalam kerangka inilah kemudian pemikiran Islam inklusif lahir merespon kondisi kebangsaan yang beragam.
\end{abstract}

Kata kunci: Islam inklusif, Pluralitas, common platform, tipologi pemikiran Islam.

\section{Pendahuluan}

Umat Islam menyikapi modernisasi penuh dengan curiga dan prasangka. Kecurigaan dan prasangka itu muncul karena modernisasi dan kolonisasi mebongkar nilai-nilai tradisional yang menyebabkan rasa kurang percaya diri umat Islam. Namun demikian, Barat membantah pernyataan bahwa kemunduran Islam disebabkan oleh Barat dan balik menyerang Islam. Menurut E. Renan dan Sir William Muir mewakili komentar Barat atas Islam menjawab, sifat rendah diri yang muncul dari Islam tersebut memang inheren dalam peradaban Islam. Telah dituduhkan semuanya itu bersumber dari inferioritas Islam, agama yang dipandang sebagai fenomena 'Badui' 
yang asing terhadap 'akal' dan toleransi. ${ }^{1}$ Dari satu sisi jawaban yang dilontarkan oleh E. Renan dan Sir William terlihat agak bias dan berlebihan, namun ada benarnya bahwa sifat inferioritas itu suatu kenyataan akibat dari penjajahan yang berabad abad oleh bangsa Eropa. Di sisi lain, sulit untuk dibantah bahwa modernisasi pada dirinya juga mengandung rasio yang memihak, superioritas, dehumanisasi dan kolonisasi. ${ }^{2}$

Untuk membuktikan pernyataan di atas kita perlu mencari akar permasalahan, mengingat kompleknya persoalan yang terkait antara kolonialisme, misionaris dan dialog antar agama. Paling tidak, mandegnya hubungan Islam dan Barat dapat ditelusuri dari awal terjalinnya hubungan antara Islam dan Barat.

Dari Abad ke-2 H/8 M hingga 4 H/10 M, serangkaian krisis intelektual dan kultural timbul dalam dunia Islam, yang paling serius dan signifikan adalah menghadapi intelektualisme Hellenis. Tetapi tantangan tersebut dihadapi Islam dengan berhasil baik dengan cara berasimilasi, menolak ataupun menyesuaikan dirinya dengan aliran-aliran baru tersebut.- karena unsur-unsur dan aliran pemikiran baru tersebut mensuplai dan membangun kandungan Islam itu sendiri. Keadaan kemudian berubah ketika datangnya dampak-dampak Barat pada Islam dalam abad ke-18 M dan khususnya abad ke $19 \mathrm{M}$. Fase pertama dari dampak ini adalah bersifat politis dan militer di mana dalam setiap kasus kaum Muslim selalu terkalahkan dan secara politis tertundukkan, baik secara langsung maupun tidak langsung. Tantangan paling besar dan langsung datang dari misionaris Kristen, pemikiran Barat Modern dan kritik Barat terhadap Islam dan masyarakat penganut Islam.

Kegoyahan yang timbul akibat kekalahan-kekalahan dan penyerahan politik menjadikan kaum Muslimin secara psikologis kurang mampu untuk secara konstruktif untuk memikirkan kembali warisan kebudayaan dan mejawab tantangan intelektual dari pemikiran modern. Tantangan modern tersebut berhadapkan langsung dengan lembaga-lembaga sosial Islam, seperti hukum-hukum perkawinan, kedudukan wanita dan kedudukan ekonomi, dan struktur sosial masyarakat yang beragam seperti di Indonesia.

Indonesia sebelum Belanda dan Portugis menjajah adalah sebuah negara dengan penduduknya yang terbentuk dari asimilasi bermacam-macam budaya dan agama seperti; Hindu, Buddha, dan Islam ( baca Gertz). Penduduk Indonesia telah beradab selama beberapa abad sebelumnya karena mereka telah melakukan teknikteknik penanaman padi dan mengembangkan bentuk-bentuk organisasi sosial tradisional. ${ }^{3}$ Pada pertengahan abad keenambelas, misi Katolik dan Protestan termotivasi oleh idealisme Kristen dan rasa pertualangan, sekelompok orang Belanda melakukan perjalanan ke tanah Jajahan. Belanda berhasil berkuasa di Indonesia setelah menaklukkan kerajaan Mataram yang Muslim. Pada masa itu sebagian besar penduduk Indonesia sudah menganut agama Islam. Sangat erat hubungannya dengan datangnya Belanda (kristen) ke Indonesia adalah kesediaan untuk menerima sesuatu yang baru baik itu budaya maupun agama. Toleransi dan kesediaan untuk menampung

\footnotetext{
${ }^{1}$ Fazlur Rahman, Islam, Penerbit Pustaka Bandung, Cet. III 1997 hal. 315

${ }^{2}$ F. Budi Hardiman, Menuju Masyarakat Komunikatif: Ilmu, masyarakat, Politik dan pormodernisme Menurut Jurgen Habermas, Penerbit Kanisius Yogyakarta, th. 1993. hal. 24. Proyek modernitas menuju masyarakat rasional sebagai perwujudan kekuasaan dalam bentuk sistem ekonomi dan administrasi birokrasi. Habermas menunjukkan cacat modernisasi dalam bentuk totalitarianisme, hilangnya makna, anomie, penyakit jiwa, alienasi dan sebaginya, katanya adalah akibat pemiskinan rasionalitas Barat pada paradigma filsafat kesadaran.

${ }^{3}$ W. F. Wertheim, Masyarakat Indonesia Dalam Transisi: Studi perubahan Sosial, Penerbit Tiara WacanaYogya, Cetakan I, th. 1999, hal. 4.,
} 
pesan-pesan baru atau asing (Kristen) merupakan faktor utama dalam pengenalan birokrasi "modern" di Indonesia. Walaupun pada proses selanjutnya hubungan yang terbentuk adalah dominasi politik dan budaya. ${ }^{4}$

Pertemuan dua kebudayaan; Barat (Kristen) yang "maju” dengan kebudayaan Indonesia (sebagian besar Islam) "terbelakang" menimbulkan konflik berkepanjangan. Kecurigaan bahwa misionaris Kristen adalah antek-antek kolonial, serta anggapan bahwa Kristen adalah agama orang Barat penjajah, semakin memperburuk hubungan dua agama besar; Kristen dan Islam. Yang mana kecurigaan itu masih berlanjut sampai sekarang ini, seperti konflik antar agama di Indonesia secara kuantitatif sering terjadi antara Islam dan Kristen ${ }^{5}$, ketimbang konflik agama antara Islam, Hindu atau Buddha.

Sikap Belanda berubah terhadap Islam di Indonesia setelah Snouck Hurgronje ${ }^{6}$ melakukan kritikan terhadap kebijakan Belanda. Hurgronje meluruskan kekeliruan masa lalu yang dibuat oleh pemerintah kolonial Belanda dikarenakan kesalahan informasi dan kurangnya pengetahuan mengenai permasalahan Muslim. Dia mengatakan bahwa ketakutan Belanda terhadap pengaruh Pan-Islamisme Turki terhadap para Haji Pribumi yang melakukan ibadah haji ke Makkah akan merubah ideologi gerakan kaum Muslim tak beralasan.

Secara umum kebijakan Hurgronge terhadap Islam didasarkan pada tiga prinsip dasar. Pertama, segala hal yang menyangkut aspek ritual, atau aspek ibadah Islam, orang harus benar-benar bebas untuk menjalankannya. Kedua, dalam urusan kelembagaan sosial Islam, atau aspek muamalat dalam Islam, seperti perkawinan, warisan, mahar, dan interaksi sosial lainnya, pemerintah kolonial harus berusaha menjaga dan menghormati keberadaannya. Ketiga, dalam masalah politik pemerintah kolonial Belanda disarankan untuk tidak menoleransi aktivitas apapun dari kaum Muslim yang mengarah perlawanan politik atau bersenjata terhadap kekuasaan Belanda. ${ }^{7}$ Pesan moral yang ditekankan oleh Hurgronge adalah menumbuhkan keyakinan dalam masyarakat bahwa pemerintah tidak mencampuri urusan keimanan masing-masing pemeluk agama, dengan cara demikian akan memperkokoh kekuasaan Belanda di Indonesia. adapun pembauran antara Indonesia yang "terbelakang" dengan masyarakat Belanda yang "modern" dapat dilakukan dengan cara meningkatkan pendidikan kaum pribumi. Akibatnya kebijakan mengenai Islam yang dikembangkan oleh Hurgronje menjadi bagian integral dari Politik Etis. ${ }^{8}$

\footnotetext{
${ }^{4}$ Dr. Alwi shihab, Islam Inklusif: Menuju sikap terbuka dalam Beragama, Penerbit Mizan Bandung Cet. VI, th. 1999, hal. 14.

${ }^{5}$ Ibid, hal. 21

6 Dr. Cristian Snouck Hurgronge lahir pada 1857 dan belajar bahasa dan peradaban Arab di Universitas Leiden dan Strassbourg, lalu menjadi profesor agama dan hukum Islam di Universitas Leiden. Kesarjanaannya makin meonjol, karena ia berhasil mengunjungi Mekkah setelah belajar beberapa lama di jeddah sejak 1884. Dalam reputasi itulah, pada 1891, Den Haag meminta jasa Snouck untuk mengatasi kegagalan militer di Aceh. Sejak itu dia menjadi penasehat pemerintah jajahan untuk masalah Islam dan Bumi Putera. Tentang ini lihat Parakitri T. Simbolon, Menjadi Indonesia: Akar-akar Kebangsaan Indonesia, Penerbit Kompas, th. 1995, hal. 491-492.

${ }^{7}$ Op. cit, hal. 16-17.

${ }^{8}$ Di negeri Belanda sendiri terjadi perubahan kebijakan untuk meningkatkan pungutan pajak di negara jajahan. Kebijakan tersebut memancing gelombang kecaman dari berbagai pihak terhadap situasi Hindia Belanda seluruhnya. Karena dianggap sebagai akibat buruk liberalisme, maka keadaan itu dikecam oleh golongan Kristen, liberal progresif, dan sosial demokrat.
} 
Pertengahan abad kesembilan belas, pemerintah kolonial mulai melakukan pendidikan terhadap anak-anak priyayi rendahan untuk dijadikan pegawai Pangrepraja rendahan, guru, dan tenaga paramedis. Ini dilakukan oleh Belanda untuk membentuk elite pribumi yang baru, menggantikan peranan tradisional kaum bangsawan. ${ }^{9}$ Kemudahan mendapatkan pendidikan Barat bagi kalangan priyayi dan naik haji bagi Ulama Muslim ke tanah suci Makkah, menimbulkan pergesekan intelektual dengan ide-ide demokrasi dan sosialisme Eropa dan gerakan Pemurnian Islam di Mesir yang dipelopori oleh Muhammad Abduh yang ketika itu membangkitkan nasionalisme Arab melawan Inggris. Persentuhan ini kemudian memunculkan beberapa corak pembaruan gerakan kebangkitan Indonesia dalam melawan kolonialisme Belanda. Pertama, mereka yang mempunyai latar belakang pendidikan Barat dan Priyayi melahirkan gerakan Nasionalis, seperti Budi Utomo, Sutomo, Suwardi suryaningrat, Cipto Mangunkusumo, dan Gunawan Mangunkusumo. Kedua, mereka yang mempunyai latar belakang pendidikan pesantren tradisional yang kuat, oleh Dawam Rahardjo disebut dengan tokoh-tokoh "ulama cendikiawan"10 seperti K. H. Wahid Hasyim dan K. H. Fakih Usman [pendiri Nahdlatul Ulama (NU)], K. H. Ahmad Dahlan (pendiri Muhammadiyah) dan K. H. Mohammad Adnan. tokoh pendiri dan konseptor PTAIN Yogya, sekarang menjadi IAIN. Ketiga, Nasionalis-Agamis-mereka yang dilahirkan dari tradisi Islam yang kuat, tetapi berlatar belakang pendidikan Barat di satu sisi dan berlatar belakang keluarga Muslim di lain sisi, seperti, Soekarno, Muhammad Hatta, Sutan Syahrir, Tan Malaka, Haji Agus Salim, dan Buya Hamka. (masih banyak tokoh lainnya, tidak memungkinkan dibahas disini).

Generasi awal kaum pribumi yang bersentuhan dengan ide-ide liberal dan demokrasi Eropa maupun dengan mereka bersinggungan dengan gerakan Islam puritan di Mesir, telah memberikan dampak yang cukup signifikan terhadap agendaagenda perjuangan di satu sisi dan cara pandang terhadap agama lain di lain sisi. Perjuangan bukan lagi atas nama agama seperti yang dilakukan ulama-ulama Muslim sebelumnya tetapi bergeser kepada suatu bentuk perjuangan melawan penindasan. Setiap pemeluk agama baik Islam, Kristen, Hindu, Buddha berjuang untuk membebaskan Indonesia dari penjajahan. Momentum penting itu diwujudkan oleh Founding Father's ketika perumusan dasar-dasar negara Pancasila. Atas nama kepentingan bersama seluruh bangsa Indonesia itulah dasar-dasar toleransi beragama diletakkan. Agama-agama diakui keberadaannya oleh negara, sebagaimana termaktub pada sila pertama dari Pancasila yang berbunyi "Ketuhanan Yang Maha Esa". Bahwa negara Indonesia terdiri dari berbagai macam agama yang percaya kepada Tuhan Yang Maha Esa.

\section{Islam Indonesia: Masalah Kemajemukan}

Indonesia adalah salah satu negara yang paling pluralistik masyarakatnya. Mayoritas penduduknya memeluk agama Islam, tetapi secara religio-politik dan ideologis, Indonesia bukan negara agama, dengan bahasa retorik harus ditegaskan, bahwa Indonesia bukan negara agama, tetapi juga bukan negara sekular". Di negeri

Abraham Kuyper, pendeta, pendiri partai Anti Revolusioner, dan pada 1901 menjadi Perdana Menteri , sejak 1879 telah menolak secara menyeluruh politik eksploitasi di Hindia Belanda. Dari program partainya itulah (program van Beginselen) muncul istilah yang kelak ikut mengokohkan apa yang disebut Politik Etis. Parakitri T. Simbolon, hal. 168-169.

${ }_{9}$ M. dawam Rahardjo, Intelektual Inteligensia dan perilaku politik Bangsa: Risalah Cendikiawan Muslim, Penerbit Mizan Bandung, Cetakan IV Maret 1999, hal. 66.

${ }^{10}$ Ibid, hal. 66. 
ini, agama agama diberi ruang untuk bergerak bebas, tumbuh dan berkembang sepanjang tidak melanggar institusi dan batas-batas toleransi antar umat beragama. Komunitas religius yang beraneka ragam tersebut masing-masing, mempunyai orientasi kehidupan sendiri. Negeri ini mengakui pluralitas masyarakat, yang diharapkan oleh konstitusi negeri ini, yaitu dengan keanekaragaman itu pemeluk agama-agama dapat berlomba-lomba dalam berbuat dan mengisi pembangunan.

Pancasila sebagai ideologi merupakan titik pertemuan berbagai kelompok kepentingan, karenanya Pancasila adalah hasil kesepakatan nasional dan konsensus masyarakat indonesia. Pancasila menjadi landasan filosofis toleransi umat beragama di Indonesia, walaupun secara eksplisit bahwa Pancasila sangat dipenuhi oleh nilainilai keislaman, ia juga terkadang diiterpretasikan sebagai sekularisme versi Indonesia. Kalangan komunis pun memanipulasi Pancasila sebagai alat legitimasi simbolik bagi mereka untuk menyingkirkan lawan-lawan politik mereka, dengan memberikan label pada lawan politiknya sebagai "anti Pancasila.

Pada tahun 1995, M. Syafi'I Anwar MA, menulis sebuah buku yang berjudul, Pemikiran dan aksi Islam di Indonesia atara lain menampilkan tipologi pemikiran politik cendikiawan muslim neo-modernis tahun 80 -an. ${ }^{11}$ Pemetaan pemikiran politik dari para cendikiawan muslim yang diuraikan oleh Syafi'I di sini sangat membantu untuk menjelaskan cara pandang masing-masing tokoh tentang posisi agama, politik, dan negara sebagai suatu yang tidak terpisahkan dari pemikiran keislaman secara keseluruhan. Karena pemikiran politik mereka bukan semata-mata membahas aspekaspek normatif-doktriner. Tetapi juga berhubungan dengan analisis, respon, dan refleksi terhadap peristiwa yang terjadi di Indonesia. Selanjutnya Syafi'I Anwar menampilkan enam tipe yang berbeda.

1. Formalistik ${ }^{12}$

Tipologi 'formalistik" menginginkan suatu orientasi masyarakat Islam yang dilembagakan dalam bentuk partai Islam untuk menyalurkan ekpresi simbolis dan idiom-idiom politik, kemasyarakatan, budaya Islam, serta eksperimentasi sistem kenegaraan Islam. Kaum formalis sangat menekankan ideologisasi atau politisasi

\footnotetext{
${ }^{11}$ Sosok cendikiawan neo-modernis Islam diwakili oleh Fazlur Rahman, lahir di Pakistan. Di Indonesia corak pemikiran cendikiawan Muslim neo-modernis - dalam hal ini diwakili pemikir dakade 80-an terutama Nurcholis Madjid dan Kuntowijoyo sebagai representasi dalam wacana "Islam peradaban". mereka saling melengkapi dalam memenuhi daur "neo-modernis" yang diperkenalkan Fazlur Rahman.

Menurut Fazlur Rahman, watak artifisial bangunan intelektual ilmiah Islam klasik, yang mengambil konstruksi teoritis dari dari gagasan Hellenisme, seperti misalnya kalam dan falsafah, telah mengundang reaksi dari kalangan ortodoksi, misalnya al-Ghazali dan Ibnu Taymiya. Intelektualisme kalangan modernis terpenggal, karena perlakuan sepotong-sepotong, ad hoc, dan seringkali sangat ekstrinsik terhadap al-Qur'an. Dan keadaan ini terus berlanjut hingga masa modern saat ini.

Menurut Rahman, ada dua tipe cendikiawan Muslim dalam merespon modernitas. Di satu sisi, mereka melakukan pengadopsian gagasan-gagasan kunci Barat dan pranata-pranatanya yang dibela mati-matian, yang sebagian diberi pembenaran dengan kutipan al-Qur'an. Sementara kelompok lain, menolak mentah-mentah modernitas dan mengajukan alternatif apologetik, berdasarkan pemahaman alQur'an scara literal.

Rahman menawarkan jalan keluar melalui dua gerakan dalam penafsiran al-qur'an: Pertama, mencari dasar etis dari suatu ayat dengan analisis historis kontektual ayat tersebut. Kedua, kita mencoba menafsirkan, menjabarkan atau menerangi problem kontemporer dengan semangat etis alQur'an yang sudah didapat itu. [Lihat Budhy Munawar-Rachman, Islam Pluralis: Wacana Kesetaraan Kaum Beriman, Penerbit Paramadina Jakarta, Maret 2001, hal. 293-294].

${ }^{12}$ Formalisasi; Inggris: formalisation; dari bahasa Latin forma (bentuk). Maksudnya adalah tendensi atau kecondongan memberikan tekanan lebih kuat pada forma (bentuk) daripada isi. Lihat, Kamus Filsafat, Loren Bagus, Gramedia Jakarta
} 
yang mengarah simbolisasi keagamaan secara formal sebagai antsipasi munculnya resistensi terhadap dominasi atau pengaruh ideo-politis dan kultural yang dianggap melemahkan potensi Islam, khususnya Barat. Peneguhan ideologi dan budaya sendiri (ideological and cultural self-assertion) muncul sebagai "alternatif" bagi sistemsistem politik lain dalam mengimbangi Barat. Paradigma pemikiran formalistik ini menurut Syafi'I tampak dalam pemikiran Mohammad Natsir ketika memperjuangkan dasar-dasar negara Islam pada Konstituante 1957. Dan Amin Rais pada era 80-an. Bagi Amin Rais, politik harus didasarkan dan ditegakkan atas prinsip-prinsip tauhid. "Bila politik berjalan lepas dari moralitas dan etika tauhid, maka politik itu akan berjalan tanpa arah, dan bermuara pada kesengsaraan orang banyak". ${ }^{13}$

Sementara itu demokrasi bagi Amin merupakan sistem politik terbaik bagi masyarakat manapun, termasuk Indonesia. "Hanya demokrasi saja yang dapat menjamin eksistensi negara kesatuan Republik Indonesia dengan kemajemukan latar belakang kultur, etnis, dan agama...demokrasi sudah terlalu jelas artinya bagi saya."(149). Penganut paradigma formalistik yang lainnya adalah A. M. Saefuddin, seorang ahli ekonomi pertanian dan staf pengajar IPB. Jalaluddin Rahmat, ahli ilmu komunikasi massa Iowa, Amerika Serikat. Hanya saja menurut Syafi'I Jalaluddin kadang-kadang juga menjadi realistis.

\section{Subtantivistik ${ }^{14}$}

Kalangan subtantivistik menekankan subtansi atau makna iman dan peribadatan lebih penting daripada formalitas dan simbolisme keberagamaan serta ketaatan yang literal terhadap teks wahyu Tuhan ${ }^{15}$. Pemahaman yang tidak kritis terhadap Hadits dan prinsip-prinsip hukum yang berasal dari mazhab-mazhab tradisional, harus diinterpretasikan kembali ke dalam pemahaman modern. Eksistensi dan artikulasi nilai-nilai Islam yang intrinsik lebih diutamakan untuk mengembangkan islamisasi dalam wajah kulturasi masyarakat Indonesia modern. Maka oleh sebab itu gerakan sebaiknya menjadi gerakan budaya, daripada gerakan politik.

Mereka yang menekankan subtansi kultural dalam proses islamisasi di indonesia adalah Nurcholis Madjid dan Abdurrahman Wahid, Prof. Dr. Harun Nasution, dan KH. Ahmad Siddiq (almarhum). Bagi Nurcholish Madjid, menyadari keterbatasan manusia yang satu dengan lainnya dalam memahami pesan Tuhan, maka kaum Muslim harus bersikap toleran satu sama lain dan termasuk non-muslim. Dengan demikian, pluralitas dan pluralisme dipandang sebagi fitrah dan kondisi kemanusiaan universal. Karena itulah perlu diresponi secara kesadaran.

3. Transformatik.

M. Dawam Rahardjo, seorang penganut dialektika empirisisme-metafisisme (demikian Syafi'I menyebutnya) yang sekarang menjadi rektor UNISMA Bekasi adalah tipe ketiga. Pemikirannya bertolak dari pandangan dasar bahwa misi Islam yang utama adalah kemanusiaan. Islam harus menjadi kekuatan yang dapat menjadi motivasi secara terus-menerus, dan mentranformasikan masyarakat dengan berbagai aspeknya ke dalam skala besar yang bersifat praktis maupun teoritis. Refleksi transformatif diimplementasikan ke dalam gerakan-gerakan pengembangan

\footnotetext{
${ }^{13}$ M. Syafi'I Anwar, Pemikiran dan Aksi Islam Indonesia: Sebuah kajian Politik Tentang Cendikiawan Muslim Orde Baru, Penerbit Paramadina Jakarta, 1995, hal. 147.

${ }^{14}$ Subtansi; Inggris: substante. Dari bahasa latin substantia (bahan, hakikat, zat, isi); dai sub (di bawah) stare (berdiri atau berada). Maksudnya adalah hal yang primer dan aspek yang sangat penting dari suatu hal. Sifal esensial dari suatu hal yang memungkinkan suatu hal dikenal dan ditentukan dan tanpanya tidak dapat ada sebagai hal itu. Op. cit, hal. 1052.

${ }^{15}$ Budhy Munawar-Rachman. Op.cit, hal. 62.
} 
masyarakat (community development) dengan pendekatan praktis: kesatuan dialektis antara refleksi dan aksi, teori, dan praktek, serta iman dan amal.

Pada tataran teoritis, Dawam berusaha membangun "teori-teori sosial alternatif" yang didasarkan pada dunia Islam sebagai alternatif terhadap kecendrungan dan dominasi positivisme yang kuat di kalangan ilmuwan dan pemikir sosial Muslim. Teori-teori sosial alterntif nantinya memberikan penjelasan bukan hanya perubahan sosial masyarakat, tetapi juga mengarahkannya untuk mencapai nilai-nilai yang dikehendaki umat, yaitu: humanisasi, libealisasi, kontekstualisasi, dan transendensi; yang disebut kemudian dengan "ilmu sosial profetis" atau ilmu sosial transformatif. Mereka yang digolongkan ke dalam pemikir transformis adalah Adi Sasono, Kuntowijoyo, dan Muslim Abdurrahman, sekalipun di antara ketiganya terdapat jurang pemikiran yang sedikit berbeda. ${ }^{16}$

4. Totalistik

Kalangan penganut pemikiran totalistik adalah yang menganggap bahwa doktrin Islam bersifat total (kaffah $)^{17}$. Islam mengandung nilai-nilai dan petunjuk yang langgeng dan komplit yang meliputi semua bidang kehidupan sosial, politik, ekonomi, serta melingkupi segi-segi individual, kolektif, maupun masyarakat kemanusiaan umumnya. Pemikiran ini menganggap bahwa tidak ada ruang kosong di luar teks dan wahyu Ilahi, maka konsekwensi dari watak totalistik adalah semua harus diresapi dengan norma Islam. Dengan demikian, tidak ada kesempatan untuk menerima kenyataan yang bersifat partikularistik atau kemajemukan.

Menurut syafi'I, tampak dari pemikiran totalistik ini mengandung penerapan unsur-unsur fundamentalisme. Karena para pemikir totalistik mempunyai kecendrungan kuat untuk mengelaborasi sebagian dari fundamentalisme. Meskipun mereka menolak keras diklaim sebagai fundamentalisme. Jika kaum Fundamentalis mempunyai kecendrungan mengutamakan "militansi tindakan-tindakan sosial politik" yang pragmatis dan anti intellektualisme, maka penganut totalistik lebih tertarik pada "militansi pemikiran" serta terbuka pada diskursus intelektual dan pendekatan ilmiah.

\footnotetext{
${ }^{16}$ Kalangan "Islam transformatif" banyak berkembang di kalangan cendikiawan yang latar belakang pendidkan bukan agama, melainkan memiliki komitmen tinggi terhadap Islam. Atau bias juga dari kalangan Agama, tetapi kemudian mengapresiasi ilmu-ilmu sosial sedemikian rupa, melebihi apresiasinya terhadap ilmu-ilmu tradisional Islam. Kebanyakan mereka adalah aktivis NGO (Non Government Organitation). Di samping itu mereka diwarnai oleh tradisi sosiologi-kritis (sekolah Frankfurt dan kalangan neo-Marxist lainnya, misalny A. Gramsci dan teori depedensia, bahkan juga teori pasca-modernisme seperti M. Foucoult). Di antara ciri mereka adalah sangat kental mempertanyakan kepentingan-kepentingan apa yang telah dibuat dalam melegitimasikan keadilan sosial, pada tingkat domestik maupun global.

Perhatian utama mereka, pertama kali ditujukan pada suatu usaha transformasi sosial. Arti Transformasi, bukan dalam pengertian "Islam peradaban", yang menekankan pada pembangunan kelas menengah Islam yang kuat secara ekonomi-politik dan komitmen terhadap nilai dasar Islam, tatapi transformasi masyarakat bawah (grass root). Dalam kata transformasi itu, termuat suatu empowering of the people untuk mengorganisir diri dalam memperbaiki harkat hidup dan martabatnya sebagai manusia yang manusiawi.

Dengan analisis keislaman ini, jadilah suatu pemikiran keislaman transformatif, atau suatu teologi emansipatoris, yang tekanannya bukan lagi mengusahakan transformasi masyarakat ke arah modern saja, melainkan mentransformasikan struktur-struktur masyarakat yang menindas, ke arah struktur yang lebih fungsional dan humanis, untuk perealisasian martabat manusia. Mereka memikirkan bagaimana agama bias berperan-paling tidak secara ideologis - dalam mengontrol mode of production dalam masyarakat. [Ibid, hal. 273-274]

${ }^{17}$ Syafi'I anwar, Op. cit, hal. 175.
} 
Mereka yang digolongkan ke dalam pemikiran totalistik adalah Dr. Fuad Amsyari. Ia adalah seorang dokter dan dewan pakar ICMI Pusat. 6)

\section{Idealistik}

Corak pemikiran idelalis yang dimaksud oleh syafi'I Anwar di sini adalah pemikiran yang bertolak dari pandangan pentingnya perjuangan umat untuk berorientasi pada atahapan menuju "Islam cita-cita" (ideal Islam), sebagaimana yang tersurat dan tersirat dalam al-Qur'an dan Sunnah yang otentik, tetapi belum lagi dirumuskan secara tuntas dan sistematis pada masa modern sekarang ini. tercermin dalam tingkah laku sosial politik umat islam dalam realitas sejarah. Sumber utama Islam cita-cita adalah cita-cita etik dan moral al-Qur'an, yang dipahami secara cerdas dan kontekstual sesuai dengan dinamika dan perubahan zaman. Cendikiawan Muslim yang punya perhatian pada bidang ini adalah Dr. A. Safi'I Maarif, MA. Ia adalah ketua Muhammadiayah dan alumni ilmu sejarah dari Ohio University dan gelar doktornya diperoleh dari University of Chicago.

6. Realistik

Tokoh yang merealisasikan pemikiran realistik adalah Dr. Taufik Abdullah. Ciri pokok pemikiran tipe ini melihat keterkaitan antara dimensi subtantif dari ajaran atau pun doktrin agama, dengan konteks sosio-kultural masyarakat pemeluknya. Bagi pemikir realistik, Islam sebagai agama wahyu yang universal dan bertolak dari kesempurnaan dan keabadian doktrin, perlu hadir dan menampakkan diri secara realistik dalam keragaman, yang diwarnai oleh perjalanan sejarah dan situasi kultural umat pemeluknya. Ketegangan antara doktrin, yang abadi, dengan manifestasi dalam kehidupan pribadi dan sosial, merupakan realitas obyektif dan pantulan dari dinamika Islam itu sendiri. Islam yang datang dari daerah asing yang terkait dengan lingkungan asalnya mengalami proses akulturasi dengan budaya setempat.

Jika menilik pada uraian di atas, tampak perbedaan dalam orientasi pemikiran pemikiran intelektual muslim generasi pra-kemerdekaan dengan generasi 80-an. Pada generasi pra-kemerdekaan pencarian intelektualisme muslim didasarkan pada kepentingan bersama untuk melawan pemerintahan kolonial yang diwadahi oleh semangat kebangsaan. Tokoh seperti Soekarno, Mohammad Hatta, Tan Malaka, dan Haji Agus Salim, yang berlatar belakang pengetahuan Barat di satu sisi dan latar belakang agama yang kuat di sisi lain, setelah mereka kembali ke Indonesia tidak menjadikan agama sebagai orientasi perjuangannya. Proses "pembaratan" terjadi secara baik, sehingga agama tidak diungkapkan dalam simbol-simbol formalistik. Berbeda dengan intelektual muslim generasi 80-an seperti diuraikan di atas, walaupun kebanyakan dari mereka belajar di Barat, kurang terpengaruh oleh pemikiran Barat. Setelah kembali dari Barat, mereka merumuskan ulang ideologi perjuangan untuk menjawab problem pembangunan yang mencari wujudnya dalam agama Islam. Tokoh seperti Amin Rais, Nurcholis Madjid, Kuntowijoyo, Adi Sasono dan lainnya, adalah tokoh yang "menyemarakkan" kembali discours keagamaan dalam bentuk pakaian yang agak lebih canggih. Mereka masih bertahan pada pemikiran bahwa persoalan masyarakat Indonesia adalah persoalan agama (Islam) dan kurang terfokus pada kenyataan real masyarakat Indonesia, yaitu ketertinggalan budaya. Keinginan para pemikir muslim mempertegas identitas Islamnya, mendorong kelompok pemikir agama lain melakukan hal yang serupa. Dapat diambil contoh, ketika organisasi Ikatan Cendikiawan Muslim Indonesia (ICMI) berdiri, muncul pula kelompok cendikiawan agama lain mengimbangi kekuatan cendikiawan Muslim. Apakah 
konflik antar agama yang terjadi di Indonesia akhir-akhir ini merupakan refleksi dari menguatnya ketegangan antar identitas keagamaan itu?

\section{Pemikiran Inklusivisme Cendikiawan Muslim Indonesia}

Mengamati perkembangan pemikiran Islam di Indonesia akhir-akhir ini, kita menyaksikan ada beberapa cendikiawam muslim neo-modernis yang mempunyai concern yang mendalam terhadap persoalan hubungan agama-agama, bahkan dialog antar agama. Di antaranya adalah Prof. Dr. Nurcholish Madjid [yang selanjutnya disingkat dengan NM], Abdurrahman Wahid, dan Kuntowijoyo. Cak Nur yang secara teoritis mengedepankan konsep titik temu, "common faltform" agama-gama secara eksplisit. Beberapa pengamat menyebut pemikiran Islam itu sebagai "teologi inklusif" ${ }^{\prime 18}$, yang commited terhadap fenomena pluralisme agama.

Gagasan Nurcholish Madjid ini dapat dijadikan sebagai entry point dalam memasuki diskursus antar agama dewasa ini. Lebih dari itu gagasan ideal yang dikedepankan NM ini sangat relevan dan kontekstual dengan tuntutan situasi dan kondisi bangsa Indonesia saat ini, mengingat peta Indonesia di hari kini tengah diwarnai oleh konflik-konflik yang bernuansa keagamaan begitu kental, baik secara langsung maupun secara tidak langsung. Sebenarnya konflik-konflik itu tersebut tidak selalu berdasarkan pertimbangan keagamaan, melainkan karena faktor eksternal, misalnya: faktor kebangsaan, kesejarahan, kesenjangan sosial-ekonomi dan politik, hegemoni kultural, kekuasaan teritorial dan lain sebagainya. Meskipun demikian tampak bahwa petimbangan religiusitas sedikit banyak mengandung semangat kebencian agama vis a vis pemeluk agama lainnya.

Pada dasarnya pandangan Nurcholish Madjid tentang hubungan Islam dan pluralisme, berpijak pada semangat humanitas dan universalitas Islam. Yang dimaksud semangat humanitas di sini terkandung pengertian bahwa Islam itu merupakan agama kemanusiaan (fitrah), atau dengan kata lain cita-cita Islam itu sejalan dengan cita-cita kemanusiaan pada umumnya. Dan kerasulan atau misi Nabi Muhammad adalah untuk mewujudkan rahmat bagi seluruh alam. Jadi bukan sematamata untuk menguntungkan komunitas Islam saja.

Pengertian Universalitas Islam secara teologis dapat dilacak dari perkataan Islam itu sendiri, yang berarti, "sikap pasrah kepada Tuhan." Dengan pengertian tersebut semua agama yang benar pasti bersifat al-islam karena mengajarkan kepasrahan kepada Tuhan. Tafsir al-Islam seperti ini akan bermuara pada konsep kesatuan kenabian (the unity of prophecy), kesatuan kemanusiaan (the unity of humanity). Kedua konsep ini merupakan kelanjutan dari konsep ke Maha Esa-an Tuhan (the unity of God/tauhid). Semua konsepsi kesatuan ini menjadikan Islam bersifat kosmopolit dan menjadi rahmat seluruh alam (rahmat-an li'l-alamin), dan

\footnotetext{
18 Di Eropa, seorang editor, Church growth Bulletin, bernama Donald McGavran mengirim surat terbuka kepada Majelis Gereja Dunia menyatakan keprihatinannya akan kemungkinan perpecahan dalam tubuh umat Kristen. Perpecahan itu terjadi antara kelompok ekuminical yang berorientasi inklusivistik dengan kelompok evangelical yang berpandangan ekslusivistik.

Di samping itu, seorang teolog terkemuka Karl Rahner dalam karyanyanya "Christianity and the non-Cristian Religions" Dalam buku ini Rahner memunculkan istilah "inklusif” dalam konteks menyikapi the Anonymous Cristian (Kristen anonim), yaitu orang-orang non-Kristiani mempunyai kebenaran dan keselamatan, sejauh mereka hidup dalam ketulusan dan kepasrahan hati terhadap Tuhan, karena karya Tuhan pun ada pada mereka, walaupun mereka belum pernah menerima Kabar Baik. Lihat, Islam Inklusif, Alwi Shihab, hal. 54.
} 
bukan bukan hanya bagi umat Islam semata. Posisi ini mengharuskan islam menjadi penegah (al-wasith), dan saksi (syuhada) di antara sesama manusia. ${ }^{19}$

Ditegaskan bahwa titik pertemuan utama antar agama-agama (samawi) ialah prinsip Ketuhanan Yang Maha Esa. Menurut Cak Nur, pesan Tuhan dari sudut pandang al-Qur'an maupun seluruh Kitab selain al-Qur'an yang turun sebelum Muhammad, adalah pesan untuk selalu bertaqwa kepada Allah. Taqwa yang dimasudkan bukan sekadar seperti ditafsirkan banyak orang "sikap takut kepada Tuhan" atau "sikap menjalankan perintah dan menjauhi larangannya" tetapi lebih menyangkut wacana "kesadaran Ketuhanan" (God-conciousness): yaitu kesadaran tentang adanya Tuhan Yang Maha Hadir (omnipresent), atau selalu hadir dalam kehidupan sehari-hari. Implikasi kesadaran ini menyangkut kesediaan umat manusia untuk menyesuaikan diri di bawah cahaya kesadaran ketuhanan. Dalam konteks diskursus teologi agama-agama, menurut Cak Nur, ada beberapa ayat yang sangat penting dan signifikan sebagai rujukan dalam mencari wacana teologi inklusif Islam dalam kesatuan agama-agama. ${ }^{20}$

Menurut Cak Nur, melalui ibadah dilakukan proses pencarian Kebenaran secara tulus dan murni, sejalan dengan sikap alami manusia yang memihak pada yang Benar dan yang Baik (fitrah). Pencarian Kebenaran secara tulus dan murni dengan sendirinya menghasilkan sikap pasrah pada Kebenaran. Sikap keberagamaan yang benar akan memberikan kebahagiaan sejati. Nabi Muhammad bersabda sebaikbaiknya agama di sisi Allah ialah alhanifiyat al-sambah. Yaitu, semangat mencari Kebenaran secara lapang dada, toleran, tidak sempit, tanpa kefanatikan dan tidak membelenggu jiwa.

Dalam pandangan Cak Nur, bahwa semua nabi dan pengikutnya adalah ahl alKitab. Tetapi, yang dimaksud ahl al-Kitab bukan hanya para Nabi dan rasul semitik (dari turunan Ibrahim), melainkan juga pembawa ajaran sikap pasrah dari India, Cina, maupun Jepang (dalam kategori agama Asia).

Sementara itu, abdurrahman Wahid juga melihat antara Islam dengan pluralisme dalam konteks manifestasi universalisme dan kosmopolitanisme ajaran islam. Ada lima jaminan dasar yang diberikan Islam kepada warga masyarakat, baik secara peroranganmaupun sebagai kelompok. Kelima dasar itu tersebar dalam literatur hukum agama (al-kutub al-fiqhiyyah) lama, yang terdiri dari (1) keselamatan fisik warga masyarakat dari tindakan badani di luar ketentuan hukum; (2) keselamatan keyakinan agama masing-masing, tanpa ada paksaan untuk berpindah agama; (3)

\footnotetext{
${ }^{19}$ Lihat, makalah ceramah budaya Nurcholis Madjid di TIM, 21 Oktober 1992, "Beberapa renungan tentang Kehidupan Keagamaan untuk Generasi Mendatang.” Dimuat dalam Ulumul Qur'an, No. 1, Vol, IV, 1993.

20 Telah kami perintahkan kepada orang

Yang diberi al-Kitab sebelum kamu

Dan (juga kepada kamu

Supaya taqwa kepada Allah (surat al-Nisa'/4:131)

Ia syari'atkan kepadamu agama yang Sama

Seperti yang Ia wasiatkan kepada Nuh

Yang Kami wahyukan kepadamu

Dan yang kami wasiatkan kepada Ibrahim, Musa dan Isa

(Yaitu) tegakkanlah agama dan

janganlah berpecahbelah dalamnya (al-Syura/42:13).
} 
keselamatan keluarga dan keturunan; (4) keselamatan harta benda dan milik pribadi di luar prosedur hukum; dan (5) keselamatan profesi. ${ }^{21}$

Namun dijelaskan kemudian oleh Abdurrahman Wahid bahwa kelima jaminan dasar tersebut hanya menyajikan kerangka teoritik,atau hanya berdimensi moralistik belaka yang tidak berfungsi, jika tidak didukung oleh kosmopolitanisme peradaban Islam. Kosmopolitanisme itu muncul dalam sejumlah unsur dominan, seperti hilangnya batasan etnis, kuatnya pluralitas budaya dan heterogenitas politik. Lebih lanjut Abdurrahman menulis,

\begin{abstract}
...Kosmopolitanisme peradaban Islam tercapai atau berada pada titik optimal, manakala tercapai keseimbangan antara kecenderungan normatif kaum Muslim dan kebebasan berfikir semua warga masyarakat (termasuk mereka yang non-Muslim). Kosmopolitanisme seperti ini adalah kosmopolitanisme yang kreatif, karena di dalamnya warga masyarakat mengambil inisiatif untuk mencari wawasan terjauh dari keharusan berpegang pada kebenaran. ${ }^{22}$
\end{abstract}

Menurut Abdurrahman Wahid, Islam yang kreatif dewasa ini sudah mulai hilang, sudah menjadi kelompok berpandangan sempit, eklusif dan formalis. Usaha untuk kembali kepada agama yang idealistik, hanya akan membuat idealisme Islam yang menghasilkan bangunan normatif Islam yang eklusif dan picik. Karena itu dibutuhkan semacam agenda baru yang mampu mengatasi keadaan kaum Muslim dewasa ini. Mirip dengan Nurcholish, Abdurrahman juga menginginkan agar universalisme dan kosmopolitanisme Islam itu tampil secara inklusif di tengah pluralitas budaya dan heterogenitas politik masyarakat.

Bagi Abdurrahman Wahid, melihat realitas objektif masyarakat Indonesia yang pluralistik, Islam sebaiknya menempatkan diri sebagai faktor komplementer, dan mendominasi kehidupan berbangsa dan bernegara. Dengan demikian format perjuangan Islam pada akhirnya adalah partisipasi penuh dalam upaya membentuk Indonesia yang kuat, demokratis, dan penuh keadilan di masa depan.

Agak lain halnya dengan Kuntowijoyo. Hubungan Islam dan pluralisme dalam perspektif subtansiasi ajaran-ajaran Islam, Dia lebih mengaitkannya dengan setting sosial-budaya. Bagi Kunto peradaban Islam merupakan suatu sistem yang terbuka. Artinya peradaban Islam mengakui sumbangan peradaban lain. Sebagai sistem yang terbuka, peradaban Islam menjadi subur di tengah pluralitas budaya dan peradaban dunia. Sekalipun demikan peradaban Islam mampu mempertahankan orisinalitas dan keotentikan yang merupakan ciri khas tersendiri. ${ }^{23}$

Bagi Kunto, Islam adalah "mata rantai dari peradaban dunia." Sebab di samping sifatnya yang universal dalam arti Islam menyampaikan atau melestarikan mata rantai ilmu pengetahuan, filsafat, dan organisasi pemerintahan dari seluruh peradaban dunia; Islampun memberikan sumbangan-sumbangan khas yang bisa diidentikkan sebagai peradaban Islam. Sebagai mata rantai peradaban umat manusia, Kunto melihat menonjolnya aspek kosmopolitanisme di dalam peradaban Islam.

\footnotetext{
21 Abdurrahman Wahid, "Universalisme islam dan kosmopolitanisme peradaban Islam," makalah pada Klub Kajian Agama "Paramadina" tahun 1988. Bersama-sama dengan makalah lainnya telah disunting oleh Budhy Munawar-Rachman dan dibukukan dengan judul kontekstualisasi Doktrin Islam dan Sejarah (Jakarta: Yayasan Wakaf Paramadina, 1994. hal. 545-552.

22 Ibid, hal. 550.

${ }^{23}$ Dr. Kuntowijoyo, Dinamika sejarah Umat Islam Indonesia, Penerbit sholahuddin press dan Pustaka pelajar, Cetakan I, th. 1994. hal. 40-46.
} 
Kosmopolitanisme itu tampak pada peradaban atau budaya kota di berbagai kota di penjuru dunia Islam.

Dengan dasar pemikiran bahwa Islam merupakan sistem yang terbuka, Kunto berpendapat bahwa umat Islam dapat menerima aspek-aspek positif dari ideologi atau paham apa pun. Akhirnya, dalam konteks politik Indonesia, Kunto berpendapat bahwa umat Islam, terutama kaum cendikiawannya haruslah bias memadukan kepentingan nasional dan kepentingan Islam.

\section{Penutup}

Kemajemukan atau pluralitas umat manusia merupakan kenyataan yang menjadi kehendak Tuhan. Di dalam al-Qur'an disebutkan bahwa manusia diciptakan berbangsa-bangsa dan bersuku-suku agar manusia saling mengenal dan menghargai. Maka pluralitas meningkat menjadi pluralisme, yaitu sistem nilai yang memandang secara positif terhadap kemajemukan itu sendiri, dengan menerimanya sebagai kenyataan dan berbuat sebaik mungkin berdasarkan kenyataan itu. Dalam kitab suci juga disebutkan bahwa perbedaan antar manusia dalam bahasa dan warna kulit harus diterima sebagai kenyataan positif, yang merupakan salah satu tanda kebesaran Tuhan. Juga terdapat dalam kitab suci tentang kemajemukan dalam pandangan dan cara hidup antara manusia yang tidak perlu ditakutkan, namun hendaknya dijadikan pangkal tolak untuk berlomba-lomba menuju berbagai kebaikan, dan bahwa Tuhan yang akan menerangkan mengapa manusia berbeda-beda, nanti ketika kita kembali kepadanya.

Ide-ide yang berkaitan dengan persoalan monoteisme dan sikap pasrah sebagaimana yang ditemukan oleh Nurkholis Madjid, Abdurrahman Wahid, dan Kuntowijoyo adalah titik tolak pandangan tentang kesatuan kenabian [Unity of Propechy] dan kesatuan kemanusiaan [Unity of Humanity], merupakan implikasi sosiologis dari konsep keesaan Tuhan [Oneness of God] akan tetapi konsep "teologi Inklusif" ini sangat kental, untuk tidak mengatakan sepenuhnya, berangkat dari idiom Islam, artinya belum bersifat universal dilihat dari sudut epistemologi agama-agama. Padahal untuk menjadi suatu "teologi universal" tidak ada cara lain, yaitu harus mampu menunjukkan bahwa adanya ide-ide yang ekuivalen dengan idiom-idiom agama atau tradisi religius lainnya. Dengan kata lain, harus diformulasikan dalam bahasa "filsafat umum". Suatu hal yang cukup berarti telah dilakukan oleh Cak Nur dalam tulisan-tulisannya adalah adanya penekanan distingsi antara esoterisme dan eksoterisme melalui diskursus pembedaan aspek eksoterisme dan eksoterisme. Kita memasuki yang disebut "filsafat perenial", yaitu pengetahuan yang selalu ada, yang bersifat universal karena berkaitan dengan yang absolut. "Ada" dalam arti di antara orang-orang yang berbeda ruang dan waktu.

Berangkat dari realitas histori-empris ini, maka urgensi dialog antar agama tak terelakan lagi. Selain untuk menggalang kerjasama antar umat beragama dalam memberikan solusi-solusi alternatif terhadap problem-problem kemanusiaan universal kontemporer, juga melalui dialog ini para pemeluk agama-agama dapat belajar memahami relung-relung keberagamaan orang lain secara komprehensif dan integral. Tanpa pretensi mensubordinasikan dan mendistorsikan keberagaman orang lain, apalagi untuk tujuan konversi agama ataupun hegemoni kultural. Bahkan melalui "dialog yang dialogis" yakni dialog yang tidak hanya mengkaji aspek-aspek eksternal agama yang berupa: doktrin, puasa, sakramen, liturgi, kitab suci, seremonial, institusi keagamaan serta doktrin-doktrin lainnya. Hal itu semua tidak bermaksud untuk 
membawa pada suatu pemahaman yang utuh mengenai suatu agama. oleh sebab itu harus mencermati dan mengkaji aspek eksternal agama yang kualitas yaitu kualitas internal pemeluk suatu agama. Dengan kata lain penghayatan dan pemaknaan para pemeluknya terhadap aspek-aspek eksternal agama tersebut, berupa pencarian hakikat di balik simbol-simbol keagamaan dan dimensi formalitas lahiriah kelembagaan agama tersebut.

\section{Daftar Pustaka}

Madjid, Nurcholish, Islam Doktrin dan Peradaban, Paramadina, Jakarta, 1996.

, Islam Agama Kemanusiaan, Membangun Tradisi dan Visi baru Islam Indonesia, Paramadina, Jakarta, 1995.

, Islam Agama peradaban: Membangun Makna dan Relevansi Doktrin Islam Dalam Sejarah, Paramadina, Jakarta, 1995.

, Islam Indonesia Memasuki Zaman Modern, Paramadina, Jakarta 1992.

, Islam Kemodernan dan Keindonesiaan, Mizan, Bandung, 1987.

, Khazanah Intelektual Islam, Ed. Bulan Bintang, Jakarta, 1984.

, Universalisme Islam dan Kosmopolitanisme Kebudayaan Islam, Paramadina, Jakarta, 1998.

Ali, Fachry, Agama, Islam dan Pembangunan, Penerbit PLP2M Yogya, th. 1995.

Anwar, M. Syafi'I, Pemikiran dan Aksi Islam Indonesia: Sebuah kajian Politik Tentang Cendikiawan Muslim Orde Baru, Penerbit Paramadina Jakarta, 1995.

Bagus, Loren, Kamus Filsafat, Gramedia Jakarta.

Bellah, Robert N., Beyond Belief: Esei-Esei Tentang Agama di dunia Modern, Penerbit Paramadina Jakarta, th. 2000.

Dialog: Kritik dan Identitas Agama, Seri Dian Intervidei, Yogyakarta.

F. Schoun, Mencari Titik Temu Agama-Agama, terj. S. Bahar, Pustaka Firdaus, 1987. 
Hans, Kung, Religius Diversity and The World Religions, Fount, London, 1987.

Hardiman, F. Budi, Menuju Masyarakat Komunikatif: Ilmu, masyarakat, Politik dan pormodernisme Menurut Jurgen Habermas, Kanisius Yogyakarta, th. 1993.

Kahin, George Mc. Turnan, Nationalism And Revolution In Indonesia, Cornel University press, 1952.

Kuntowijoyo, Dinamika sejarah Umat Islam Indonesia, Sholahuddin press dan Pustaka Pelajar, Cetakan I, th. 1994.

, Paradigma Islam: Interpretasi Untuk Aksi, Mizan, Bandung, 1991.

Munawar-Rachman, Budhy, Islam Pluralis: Wacana Kesetaraan Kaum Beriman, Paramadina Jakarta, Maret 2001.

Panikkar, Raimundo, Dialog Intra Religius, Ed. A. Sudiarja, Kanisius, Yogyakarta, 1994.

Rahardjo, M. Dawam, Intelektual Inteligensia dan Perilaku Politik Bangsa: Risalah Cendikiawan Muslim, Penerbit Mizan Bandung, Cetakan IV Maret 1999

Rahman, Fazlur, Islam, Penerbit Pustaka Bandung, Cet. III 1997.

Tema-Tema pokok Al-Qur'an, terj, Anas Mahyudin, Pustaka, Bandung, th. (...)

Robetson, Roland, Agama Dalam Analisa dan Interpretasi Sosiologis, Rajawali Pers, Jakarta, th, 1995.

Shihab, Alwi, Islam Inklusif: Menuju Sikap Terbuka dalam Beragama, Mizan Bandung, Cet. VI, th. 1999.

Simbolon, Parakitri T., Menjadi Indonesia: Akar-akar Kebangsaan Indonesia, Kompas, th. 1995

Smith, Huston, Agama-agama Manusia, terj, S. Bahar, Obor, Jakarta, 1985.

Turner, Bryan S., Sosiologi Islam: Suatu Telaah Analitis atas Tesa Sosiologi Weber, Rajawali Press, cet. I, th. 1991

W. C. Smith, Religius Diversity, Ed. W. G. Octoby, Harper and Row, New York, 1976. 
Wahid, Abdurrahman, "Universalisme islam dan kosmopolitanisme peradaban Islam," makalah pada Klub Kajian Agama "Paramadina" tahun 1988. Bersama-sama dengan makalah lainnya telah disunting oleh Budhy Munawar-Rachman dan dibukukan dengan judul Kontekstualisasi Doktrin Islam dan Sejarah (Jakarta: Yayasan Wakaf Paramadina, 1994.

Wertheim, W. F., Masyarakat Indonesia Dalam Transisi: Studi Perubahan Sosial, Tiara WacanaYogya, Cetakan I, th. 1999.

* Tasman: Dosen pada Fakultas Dakwah dan Ilmu Komunikasi U Jakarta dan Peneliti Pusat Pengkajian Islam dan Masyarakat UIN Jakarta. 